\title{
Discussion Paper The Lingering Fiscal Effects of the COVID-19 Pandemic on Higher Education
}

\section{Robert Kelchen}

\section{Seton Hall University and}

Federal Reserve Bank of Philadelphia

Consumer Finance Institute Visiting Scholar

\section{Dubravka Ritter}

Federal Reserve Bank of Philadelphia

Consumer Finance Institute

\section{Douglas Webber}

Temple University and

Federal Reserve Bank of Philadelphia

Consumer Finance Institute Visiting Scholar
DP 21-01

May 2021

https://doi.org/10.21799/frbp.dp.2021.01 


\title{
The Lingering Fiscal Effects of the COVID-19 Pandemic on Higher Education
}

\author{
Robert Kelchen* \\ Department of Education Leadership, Management, and Policy, Seton Hall University \\ Dubravka Ritter ${ }^{\dagger}$ \\ Consumer Finance Institute, Federal Reserve Bank of Philadelphia \\ Douglas Webber ${ }^{\S}$ \\ Department of Economics, Temple University
}

May 2021

\begin{abstract}
The unprecedented challenges from COVID-19 present many institutions of higher education with liquidity, and even solvency, concerns. In this report, we provide guidance to institutions and policymakers about the short- and medium-term revenue losses that are likely to materialize as a result of the ongoing pandemic and associated disruptions to revenue and expenses. Using historical data on states' responses to previous economic downturns and contemporaneous measures of the severity of the current economic predicament, we project state and local appropriation reductions that public colleges and universities are likely to experience. We then use these projections in conjunction with measures of the pandemic's severity at the local level - mobility on campus and in local areas, consumer spending, fall 2020 enrollment, and more - to project likely revenue losses to institutions from appropriations and two other key revenue sources: net tuition revenue and revenue from auxiliary enterprises. We project that losses in state and local appropriations are likely to be about half the magnitude of losses in the Great Recession, or on the order of $\$ 17$ billion to $\$ 30$ billion over the period 2020 2025. However, appropriations represent a relatively small fraction of the cumulative revenue losses from the three main revenue categories, which we estimate to be $\$ 70$ billion to $\$ 115$ billion over the next five years. The extent of revenue losses depends crucially on assumptions about the pace of economic recovery. We find that most public colleges, private nonprofit colleges, and rural colleges will experience moderate cumulative losses (no loss, loss $<25 \%$ of 2019 revenue) over the next five years, while cumulative revenue losses will be the most severe ( $>50 \%$ of 2019 revenue) among institutions with fewer than 1,000 students, Historically Black Colleges and Universities (HBCUs), and certain for-profit colleges as a result of the COVID-19 pandemic.
\end{abstract}

Keywords: higher education, college, university, appropriations, enrollment, tuition, revenue, budget, COVID-19, pandemic

JEL Classification Numbers: I22, I23, I28

\footnotetext{
* 413 Jubilee Hall, 400 South Orange Avenue, South Orange, NJ 07079; e-mail: robert.kelchen@shu.edu.

$\dagger$ Federal Reserve Bank of Philadelphia, Ten Independence Mall, Philadelphia, PA 19106-1574; email: dubravka.ritter@phil.frb.org.

$\S 1301$ Cecil B. Moore Ave., Philadelphia, PA 19122; email: douglas.webber@temple.edu.
}

Disclaimer: This Philadelphia Fed Discussion Paper represents preliminary research that is being circulated for discussion purposes. The views expressed in these papers are solely those of the authors and do not necessarily reflect the views of the Federal Reserve Bank of Philadelphia or the Federal Reserve System. Nothing in the text should be construed as an endorsement of any organization or its products or services. No statements here should be treated as legal advice. We thank Daniel Moulton for outstanding data science expertise and Veronika Konovalova, Ian McGroarty, Alison Tintera, and Bryant Wright for excellent research assistance. Any errors or omissions are the responsibility of the authors. Philadelphia Fed Discussion Papers are free to download at https://philadelphiafed.org/consumer-finance-institute/publications. 


\section{Introduction}

American higher education is in its most precarious financial position since the Great Recession due to the coronavirus pandemic and the ensuing recession. Colleges and universities lost billions of dollars in revenue by suspending in-person classes in spring 2020, and these losses have continued to mount during the subsequent year. Colleges whose classes remained partially or entirely online continued to lose revenue from dining, housing, and other campus services, and many of these colleges have faced pressures to freeze tuition prices and increase student financial aid. Colleges that resumed in-person classes have generally done so with reduced campus density and increased standards for cleaning and personal protective equipment, incurring additional costs.

At the same time, enrollment fell during the pandemic instead of increasing, as is typically the case during recessions. Overall enrollment declined by $2.5 \%$ between fall 2019 and fall 2020, with much larger losses among community colleges (10\%), first-time students (13\%), and new international students (43\%) (Baer and Martel, 2020; National Student Clearinghouse, 2020). To help reduce budget shortfalls, higher education laid off large numbers of employees. Higher education employment fell by 13\% between February 2020 and February 2021, wiping out more than a decade of employment increases (Bauman, 2021).

The pandemic is likely to affect the higher education sector for years to come - well after the public health crisis has passed. Real state spending for public higher education hit its post-Great Recession low point in fiscal year 2013, and there was not a full recovery to prerecession levels until 2018 (Kelchen et al., 2020). Even though fiscal year 2020 state funding was generally steady thanks to an influx of federal funding (Laderman and Tandberg, 2021), funding challenges will be likely in the next several years. Students and their families will struggle to afford tuition increases until their economic situations improve. And even once that happens, a shrinking number of high school graduates in much of the country will reduce colleges' pricing power.

Higher education has a crucial role to play in fostering economic and social mobility, as the returns from a college education are large (Doyle and Skinner, 2017; Oreopoulos and Petronijevic, 2013; Webber, 2016). Colleges can also help close long-standing gaps in earnings and well-being by race/ethnicity, academic preparation, and family income (Chetty et al., 2017; Hout, 2012; Ost et al., 2018). But it will be challenging for colleges to support students through graduation if institutions are struggling to survive and are forced to make substantial budget cuts. Research shows that increased spending improves student outcomes (Deming and Walters, 2017; Webber and Ehrenberg, 2010), so 
reducing spending on students could exacerbate already large completion gaps across different groups of students.

Because the pandemic will have lasting ramifications for students and colleges alike, it is crucial to understand the financial implications of the COVID-19 pandemic and the ensuing recession on higher education. To do this, we bring in an array of historical and current data sources that provide insights on how colleges have been affected by the pandemic since March 2020. First, we use historical data on state general revenues and appropriations for higher education to estimate how large state appropriations might be in years after the pandemic. Then, we combine these estimates with data on the reduction of economic activity on college campuses to forecast reductions in state appropriations, net tuition revenue, and auxiliary revenue at the institution level. We then characterize the extent and distribution of financial distress due to the COVID-19 pandemic over the next five years.

We project that losses in state and local appropriations are likely to be about half of the magnitude of losses in the Great Recession, or on the order of $\$ 17$ billion to $\$ 30$ billion over the period 2020-2025. However, appropriations represent a relatively small fraction of the cumulative revenue losses from the three main revenue categories, which we estimate to be $\$ 70$ billion to $\$ 115$ billion over the next five years. The extent of revenue losses depends crucially on assumptions about the pace of the economic recovery. We find that most public colleges, private nonprofit colleges, and rural colleges will experience moderate cumulative losses (no loss, loss $<25 \%$ of 2019 revenue) over the next five years, while cumulative revenue losses will be the most severe ( $>50 \%$ of 2019 revenue) among institutions with fewer than 1,000 students, Historically Black Colleges and Universities (HBCUs), and certain forprofit colleges as a result of the COVID-19 pandemic.

\section{Higher Education Revenues and Expenditures}

American higher education is an incredibly diverse landscape of over 6,000 public, private nonprofit, and for-profit colleges that receive federal financial aid dollars. Each fiscal year, public and private nonprofit institutions alone employ over 3 million full-time equivalent staff, enroll nearly 25 million

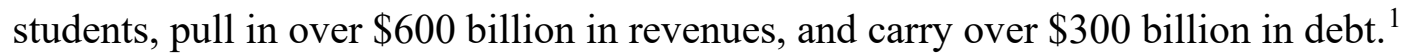

Colleges and universities rely on a number of revenue sources to support their operations. Table 1 shows the amount of money that public and private nonprofit institutions received from each of the

\footnotetext{
${ }^{1}$ Throughout this paper, we will refer to fiscal year statistics for states and institutions of higher education because most available data are measured in this way. With a few notable exceptions, a fiscal year runs from July of the previous year to June of the current year. For example, fiscal year 2021 runs from July 1, 2020, through June 30, 2021, in most states.
} 
main sources in fiscal year 2019 using data from the U.S. Department of Education's Integrated Postsecondary Education Data System (IPEDS). We describe these revenue sources in greater detail in this section. For our empirical analysis of the higher education revenue reductions as a result of the COVID-19 pandemic, we focus on the three broad types of revenue that have been the most affected due to the public health crisis: net tuition revenue, state and local funding, and revenue from auxiliary sources, such as residence halls and events. Revenue from private gifts and endowment returns, revenue from the federal government, and hospital revenue are likely to remain relatively stable in the near future, although pressure on these sources could certainly emerge in the future. ${ }^{2}$

\section{Net Tuition Revenue}

Revenue from tuition and fees (after excluding institutional grant aid to students) is the single largest revenue source for the private nonprofit college sector and a close second to state funding for public higher education. Inflation-adjusted tuition and fees have increased faster than inflation nearly every year over the last several decades. The cumulative effect of these increases is that the listed price of tuition and fees has doubled over the last three decades at community colleges and private nonprofit universities and tripled at public universities (Ma et al., 2019).

Colleges have traditionally responded to recessions by increasing tuition and fees to make up for declines from other revenue sources. The first year immediately following the beginning of the Great Recession (2009-2010) saw private nonprofit colleges increase tuition by 5.9\%, community colleges increase tuition by $10.1 \%$, and public universities increase tuition by $9.4 \%$. A similar pattern, especially at public colleges, held following the recession in the early $2000 \mathrm{~s}$.

Although the listed price of tuition and fees has increased steadily, many colleges have struggled to increase net tuition revenue after subtracting institutional grant aid to students. The median tuition discount rate at private nonprofit colleges rose from $36 \%$ in 2010 to $48 \%$ in 2019, placing colleges under financial stress (Redd, 2020). Additionally, early evidence from the current recession shows that net tuition and fee prices fell by $0.7 \%$ during the summer of 2020, the largest decline since 1978 (BauerWolf, 2020).

\footnotetext{
2 There are some two dozen urban university hospitals that may have suffered significantly due to COVID-19, but they are likely the exception. In addition, some institutions (such as California Institute of Technology) derive the majority of their revenue from government contracts with entities such as the U.S. Department of Defense, and we expect those revenue streams to remain relatively stable through the COVID-19 pandemic as well.
} 
States frequently restrict how much public colleges can increase tuition for in-state students. Fourteen states had formal limits in place for tuition in fiscal year 2018 (Kelchen and Pingel, 2018), while legislatures and governors push for smaller tuition increases through threats to cut funding or through the selection of governing board members (Kelchen, 2018). This has led public universities to prioritize recruiting and enrolling out-of-state students who pay far higher tuition prices (Jaquette and Curs, 2015). At selective public universities, this has crowded out in-state residents and underrepresented minority students in particular (Curs and Jaquette, 2017; Jaquette et al., 2016).

\section{State Funding}

State funding for public higher education is especially volatile during recessions, as it is one of the few portions of the state budget that is not determined by constitutional or legal spending requirements and has the ability to raise its own revenue. This results in higher education being used as a balancing wheel (Delaney and Doyle, 2011, 2018; Hovey, 1999), with large cuts in appropriations during recessions as states try to meet their balanced budget requirements. This results in even larger declines in per-student funding for public higher education because enrollment (especially at community colleges and broadaccess four-year universities) increases sharply during typical recessions (Barr and Turner, 2013).

Per-student state funding for public higher education declined precipitously during the Great Recession, even as the American Recovery and Reinvestment Act of 2009 contained a maintenance of effort provision that restricted most states from cutting appropriations below FY06 levels in exchange for federal stimulus funds (Alexander et al., 2010). Between fiscal years 2009 and 2014, appropriations per full-time student declined from $\$ 8,232$ to $\$ 7,129$ (in 2019 dollars). Appropriations had nearly recovered to prerecession levels by fiscal year 2019 (Laderman and Weeden, 2020). ${ }^{3}$ States immediately responded to the pandemic by making midyear budget cuts in fiscal year 2020 (Open Campus, 2020). Even with more than $\$ 2$ billion in federal funding to shore up state support for public higher education, 20 states reduced appropriations for fiscal year 2021 — the most since 2012 (Laderman and Tandberg, 2021).

Reductions in state funding have been shown to have negative effects on students. Webber (2017) showed that nearly one-third of cuts in state funding since 2000 were passed along to students in the form of higher tuition and fees, and this pass-through rate has increased over time. This raises

\footnotetext{
${ }^{3}$ Our analysis uses the Consumer Price Index instead of State Higher Education Executive Officers Association (SHEEO)'s typical Higher Education Cost Adjustment to adjust for inflation.
} 
concerns because minority and low-income students are often more sensitive to tuition increases (Allen and Wolniak, 2019; Flores and Shepherd, 2014) and because cuts to student services designed to mitigate tuition worsen student outcomes (Deming and Walters, 2017; Webber and Ehrenberg, 2010). Additionally, research by Chakrabarti et al. (2020) shows that increases in state funding for higher education are associated with increased completion rates, reduced student debt, and improved postcollege outcomes.

\section{Auxiliary Revenues}

Auxiliary revenues come from sources such as housing and dining, hospitals, athletics, and other oncampus activities that are not directly tied to instruction, research, or student services. These revenue sources tend to be the largest part of the budget at two types of institutions. The first type is small private liberal arts colleges, which often derive $20 \%$ or more of their total revenue from room and board. The second type is research universities with attached hospital systems that often represent a large portion of total revenue. For example, Ohio State University, the University of Iowa, Temple University, the University of Alabama-Birmingham, and Stony Brook University all received at least half of their total revenue from hospitals in fiscal year 2018 (authors' calculations using IPEDS data).

These auxiliary enterprises are generally expected to be self-sustaining at the least (National Association of College and University Budget Officers, 2020a) and ideally generate excess revenue to support academic operations. And because they are typically a stable revenue source that is not supported by state appropriations, public colleges in particular take on additional debt to finance facilities for auxiliary enterprises (Denison et al., 2014) or enter into public-private partnerships that bring in private companies to build and maintain these facilities in exchange for revenue or occupancy guarantees (McClure et al., 2017; Storms et al., 2017).

While auxiliary revenue sources are typically among colleges' most stable budget lines, this is not the case during the current pandemic. Hospital systems attached to research universities saw large losses as a result of elective and nonessential procedures, which generate a significant portion of revenues, being postponed or cancelled. For example, the University of Michigan's hospital projected a $\$ 230$ million budget deficit to end fiscal year 2020, which is a sizable portion of the overall estimated budget deficit for the entire University of Michigan system (Greene, 2020; Witsil, 2020).

Housing and dining revenues went from normal levels to zero in a matter of days in March 2020, resulting in colleges losing approximately $25 \%$ of their expected fiscal year revenue due to campus 
closures. Colleges had to issue refunds or credits to students, which created short-term liquidity pressures for some institutions until funds from federal bills such as the Coronavirus Aid, Relief, and Economic Security (CARES) Act arrived to help cover the expense. After a summer with limited revenue from campus activities, colleges varied considerably in their on-campus density during fall 2020 and spring 2021. Colleges that entered into public-private partnerships faced pressure to keep occupancy above certain levels to satisfy their contracts (Seltzer, 2020), but occupancy was still well below 2019 levels in fall 2020 (Williamson, 2020).

Finally, lost revenue from athletics is a significant factor for universities competing in NCAA Division I sports. The NCAA saw a decline of more than $50 \%$ in revenue in fiscal year 2020 following the cancellation of the men's basketball tournament in March 2020. This resulted in a decline of nearly $\$ 400$ million in payments to individual colleges and athletic conferences (Berkowitz, 2021). Students and taxpayers provided nearly $\$ 3.2$ billion in direct subsidies for athletics at public Division I universities in fiscal year 2019, or nearly $30 \%$ of athletics budgets (USA Today, n.d.). This percentage is likely to increase substantially through the end of the pandemic, even as colleges cut sports in a costsaving effort (Anderson, 2020).

\section{Gifts and Endowment Returns}

An important source of revenue for a small share of higher education — and one that has remained stable throughout the pandemic - is gifts and endowment returns. Support from private donors represented nearly one-third of all revenue for private nonprofit colleges in fiscal year 2019. These sources play a lesser role for public institutions, which tend to have significantly smaller per-student endowments than private colleges (Baum and Lee, 2018). Public universities represent $62 \%$ of full-time equivalent student enrollment at the four-year level, but they only have $25 \%$ of all endowment dollars (Baum et al., 2018). Endowment assets are heavily concentrated at a small number of universities, with just five institutions holding more than one-fifth of all endowment dollars in the United States (Redd, 2020).

Donors typically restrict gifts to be used for particular purposes such as student financial aid, endowing faculty positions, or building and maintaining facilities. Some of these gifts may be intended for immediate use, while other donors will designate that the gift be placed into a separate endowment fund. In the latter case, a college will typically spend between $4 \%$ and $5 \%$ of the value of the fund each 
year with the expectation that the endowment will see a larger return than the spending rate (American Council on Education, 2014).

Annual endowment returns are highly volatile and follow stock market trends closely, especially for smaller colleges that cannot access hedge funds or alternative investment strategies. During the Great Recession, the median endowment had a return of $-19.1 \%$ in fiscal year 2009 . There were then doubledigit returns in 2010, 2011, 2013, 2014, and 2017 sandwiched around small negative returns in 2012 and 2016 (National Association of College and University Business Officers, 2020b). To this point, endowments have likely avoided the large drops seen during the Great Recession, giving some colleges additional financial flexibility. Only a small percentage of colleges indicated that they plan to temporarily increase the endowment payout rate to help plug budget gaps (Lederman, 2020).

\section{Expenditures}

The costs of operating a college have risen faster than general inflation for decades, with expenses for employee benefits and administrative salaries rising more rapidly than faculty salaries and utilities (Commonfund Institute, 2019). As an industry that relies heavily on highly educated labor that cannot readily be replaced by technology, higher education suffers from Baumol's (1967) cost disease. Research by Archibald and Feldman (2008) shows that Baumol's cost disease explains most of the historic rise in higher education costs. However, Bowen's (1980) revenue theory of costs, in which colleges will spend as much money as possible to pursue quality and prestige, also plays a role.

The majority of colleges' budgets are devoted to three main areas: personnel, facilities, and debt service. It is difficult to generate major cost savings in any of these areas in the short term, even though higher education employment fell to pre-Great Recession levels by early 2021 (Bauman, 2021). Employee furloughs and pay cuts can save some money, while layoffs may generate little in short-term savings due to the need to provide severance packages to many full-time employees. In-person facilities still need to be maintained, although there could be some savings on utilities if buildings are not being occupied. Finally, colleges can only save money on debt service by refinancing loans or renegotiating payment structures.

As a result of the pandemic, colleges incurred additional expenses that were not in their original budgets. To move classes online, many colleges had to provide laptops and other equipment to students and employees and spend money on redesigning courses. Research has shown that there are at most modest cost savings for providing high-quality courses online relative to in person, but those savings 
may take years to realize after making an upfront investment (Deming et al., 2015; Ortagus, 2020). Colleges also spent large sums of money modifying campuses to meet coronavirus safety guidelines and providing personal protective equipment to students and employees.

\section{Data Sources}

We began with information on institutional characteristics, enrollment levels, and finances from the U.S. Department of Education's Integrated Postsecondary Education Data System (IPEDS). We used enrollment by undergraduate/graduate student status, race/ethnicity, and gender from fall 2019. We also used total revenue and expenses, education-related expenditures (instruction, academic support, and student services), gifts/investment return, and total assets from fiscal year 2019.

The most real-time indicator of individual colleges' enrollment and financial position comes from Title IV volume reports from the Department of Education's Office of Federal Student Aid. We used the change in aid between July and September 2020 and the same period in 2019. We focused on three measures: the total amount of Pell Grants, undergraduate student loans (including Parent PLUS loans), and graduate student loans. These measures are reported at the OPEID level, which combines certain systems of higher education (such as Rutgers University and Ohio State University) into one unit of analysis, while leaving other institutions (such as the University of Wisconsin and Indiana University systems) at the IPEDS individual college (UNITID) level. In the case of the parent/child reporting relationship at the OPEID level, we allocated aid across parent and child institutions on a per-FTE basis (Kelchen, 2019).

We used National Student Clearinghouse (NSC) data on state-by-sector percentage changes in enrollment between the fall 2019 and fall 2020 semesters. The NSC presented data for up to four sectors of higher education in each state: four-year publics, two-year publics (including certificate-granting institutions), four-year private nonprofits, and a catchall category of other colleges. About $70 \%$ of enrollment in the other colleges category was in the four-year for-profit sector, with the remainder of enrollment split between two-year for-profit colleges and two-year private nonprofit colleges. The NSC classifies colleges based on the IPEDS category of highest degree awarded, which means that community colleges with a small number of baccalaureate degree programs were counted as four-year colleges instead of two-year colleges. As such, we had to use this classification in our analyses.

The NSC only reported data for all four sectors in 13 states, as they required at least three institutions reporting data in each sector to present an estimate. However, we were able to impute 
enrollment for the missing sector (typically the other colleges category) if three of four sectors were reported. Eight states (Alaska, Arizona, Indiana, Nevada, Rhode Island, Tennessee, Vermont, and Wyoming) had enrollment data for only one or two sectors. In those cases, we imputed the same enrollment changes across each missing sector after subtracting the sector with available data. Finally, Delaware did not have enough institutions in any sector to have sector-level data. In that case, we applied the state-level change to colleges from all sectors.

To generate predictions of future state appropriations, we collected historical state revenues up to and including 2019 from National Association of State Budget Officers (NASBO) reports, and future state revenue projections for 2020-2021 from the NASBO Fall 2020 Fiscal Survey of States. We collect data on preliminary and predicted 2020 and 2021 revenues from the fiscal survey report to supplement the historical data. For 2022-2025, we assumed state revenues will follow the same path as that of the Congressional Budget Office's (CBO) projected gross domestic product (GDP). Given that the pandemic is likely to continue hampering economic activity in 2021 and possibly 2022, we consider these revenue assumptions to be somewhat optimistic.

We accessed historical data on state funding for public higher education from SHEEO. For 2020 and 2021, we relied on the annual Grapevine survey conducted by Illinois State University, which represents a first look at state funding for higher education for the current fiscal year (Applegate, 2021). We focused on the one-year change in funding between fiscal years 2019 and 2020, and the two-year change in funding between fiscal years 2019 and 2021 to show the difference in state support during the pandemic versus before the pandemic began. Importantly, Grapevine also collects data on CARES Act funding, which allowed us to separate appropriation funding that comes directly from the state versus from the federal government via CARES Act funding.

To approximate foot traffic on college campuses (which is likely to correlate with changes in auxiliary revenue), we use data on "pings" from individual phones from SafeGraph, a data company focusing on the physical world that collects anonymous, aggregated locational information from consumers who have opted in to sharing their location through mobile applications. Each observation includes a unique device identifier associated with a single anonymous consumer, the time and date of the ping, and the latitude, longitude and accuracy of the ping over a sample period from January 2018 through December 2020. From the data, we construct measures of year-over-year changes in the number of visitors, number of visits, and length of visit (time spent at a location) on each college campus based on shapefiles of institutional locations. To approximate activity during the fall semester, we used year- 
over-year changes between April and December 2020 and April and December 2019 (at the UNITID level).

For further input on economic activity in the campus area, we used data on settled credit and debit card transactions from Womply. The company is focused on serving small business and receives aggregated transactions for businesses that process their payments with one of Womply's payment processing partners. The anonymized data are at the individual transaction level with corresponding business location (county and state) and merchant category, covering January 2015 to December 2020. We approximate the effect of COVID-19 on campus spending by calculating year-over-year changes between April-September 2020 and April-September 2019. We consider changes in general spending at the county level and spending in the higher education merchant category at the state level (because there are not enough higher education transactions at the county level for reliable estimates).

\section{State Appropriation Projections}

The Great Recession wreaked havoc on state budgets and consequently funding for public colleges and universities. Figure 1 shows the total state revenues and higher education appropriations for a group of representative states. The decline in appropriations consistently lags the downturn in revenue (all states presented in Figure 1). Appropriations do not fully recover until well after the revenue recovery (e.g., Georgia, Missouri, Washington) and, in states like Pennsylvania, they remain at permanently reduced levels. Additionally, appropriations tend to exhibit a greater level of variation than revenues because higher education expenditure typically represents a discretionary line item that is more likely to end up on the chopping block than other expenditure categories.

Taking advantage of the historical revenue and appropriations data, we estimate a time series regression that models state appropriations as a function of the prior two years of state tax revenue. This parsimonious specification produces the best fit when examining the pattern of state support for higher education during the Great Recession. To measure the states' capacity to provide for higher education, we exclude federal funding (e.g., from the CARES Act) from appropriation data for 2020 and (estimated) 2021 in our regression. Consistent with the descriptive evidence noted previously, our coefficient estimates indicate that state appropriations are generally unaffected in the exact year of a downturn due to the lag in the legislative process. By the time the pandemic hit in March 2020, most states were already well into the process of approving a fiscal year 2021 budget, although some states made revisions during the approval process or after the budget was signed into law. We then use the 
estimated coefficients to project state support for higher education in fiscal years 2022 through 2025 by combining them with projected state revenues described in the previous section. ${ }^{4}$ We then adjust our projections for accuracy relative to fiscal year 2017 actual appropriations.

Our results indicate that the effect of the COVID-19 pandemic on higher education funding from states will be significant, but the magnitude of the funding cuts we anticipate will be approximately half of that during the Great Recession. Intuitively, this is because state revenues have fallen less sharply due to the COVID-19 pandemic compared with the revenue drops during the Great Recession. In Figure 2, we show the distribution of state revenue in 2019 dollars relative to its value prerecession during the Great Recession $($ base year $=2008)$ and during COVID-19 (base year $=2019) .{ }^{5}$ Revenues dropped more uniformly during the Great Recession, but only some states are experiencing (and are expected to continue to experience) revenue shortfalls during the COVID-19 pandemic. Consequently, as displayed in Figure 3, appropriations are projected to drop in some states, but not in others.

As the onset of the COVID-19 pandemic occurred so late in the 2020 legislative appropriations cycle, fiscal year 2020 (and, to a lesser extent, fiscal year 2021) appropriations were unaffected, so the impacts are expected to begin manifesting in earnest beginning with the 2021 academic year and going forward (assuming the same pattern from the Great Recession holds true again). Our projections for state appropriations going forward are quite different than what they would have been had we written this report even six months ago due to the injection of federal money that has softened the effect of the pandemic on appropriations from states. Using the most recent state budget data, we show in Figure 4 that only nine states will see marked declines relative to a baseline of 2019 appropriations in fiscal year 2020, and 14 states are expected to experience the same in fiscal year 2021. What is more, the dollar amounts of these shortfalls (under $\$ 1$ billion in 2020, about $\$ 4$ billion in 2021) are relatively modest, once we consider CARES Act funding of about $\$ 2.25$ billion across the two fiscal years.

The subsequent years are where our analysis predicts an increase in the incidence of higher education appropriation reductions - 19 states in 2022-2025, and approximately $\$ 7$ billion per year in dollar terms. Put another way, by 2025 , state appropriations are expected to decline by a cumulative $\$ 30$ billion relative to the 2019 baseline, compared with approximately $\$ 60$ billion between 2009 and 2014 during the Great Recession. We do not mean to imply that some states will not be significantly strained

\footnotetext{
${ }^{4}$ We can make the appropriation projection estimates available upon request.

${ }^{5}$ The labels for each state are not necessarily legible, but individual state trends are not the emphasis of this chart. Rather, we provide the comparison in the two panels to illustrate: 1) the dispersion in revenues in the actual data compared with our projections, and 2) the trend in recovery evident from each panel.
} 
by state budget cuts in the next few years. In fact, we expect states such as Michigan to be likely to face large revenue shortfalls. If legislatures respond as they did in past recessions, the public institutions in those states would see a meaningful decline in state investment. We also emphasize that the relatively less severe reductions in state appropriations in 2020 and 2021 are not necessarily indicative of the cuts that are likely to follow as states begin to feel the effects of the revenue shortfalls during the pandemic. Indeed, most of the fiscal pain for higher education is yet to come.

\section{College-Level Funding Reductions}

Reductions in state and local appropriations to colleges and universities are certainly a cause for concern, and our estimates in Section IV demonstrate that public colleges and universities will face significant losses of appropriation funding in the next five years. However, as discussed in Section II, a considerable amount of revenue for institutions of higher education comes from other sources, most notably net tuition revenue and auxiliary revenue. To explore the prevalence and severity of potential losses of those revenue streams, we begin with the most recent information on individual college and university finances found in the 2018-2019 (in other words, fiscal year 2019) IPEDS data and consider potential changes to revenue from various sources as a result of the COVID-19 pandemic. We combine data on net tuition revenue, auxiliary revenue, and state/local appropriations to estimate likely fiscal repercussions of three different postpandemic economic recovery scenarios at the institution level. ${ }^{6}$

Our data sources and simplifying assumptions are as follows:

\section{- Net tuition revenue}

○ For fiscal year 2020, we assume enrollment and net tuition revenue remain unchanged relative to fiscal year 2019, which is consistent with a relatively stable fiscal environment leading up to the pandemic.

○ To approximate the enrollment and net tuition revenue change for fiscal year 2021 (roughly corresponding to academic year 2020-2021), we calculate the percent change in each institution's overall Title IV funding between 2020-Q4 and 2019-Q4 based on quarterly data from the Department of Education. Our implicit assumption is that the change in overall net tuition revenue follows the change in financial aid revenue, which is

\footnotetext{
${ }^{6}$ While we consider our aggregate estimates to be reasonable, we recognize that our projections will be noisy at the individual institution level. Therefore, we will not be reporting any projections at the college/university level.
} 
reasonable because we are not aware of reports of different enrollment reductions for full pay compared with financial aid students. For institutions for which Title IV aid data is missing, we use sector-state specific enrollment changes from Clearinghouse data instead.

- Then, we consider three potential scenarios for fiscal years 2021-2025:

- Optimistic scenario: Net tuition revenue loss in 2020 is equal to the Title IV funding change, then net tuition revenue reverts to the 2019 level in 2021-2025. In this scenario, all students who sat out academic year 2020-2021 return to higher education in fall 2021, such that any net tuition revenue loss was only temporary.

- Realistic scenario: Net tuition revenue loss in 2020 is equal to the Title IV funding change, then linear recovery over the following five years is back to 2019 net tuition revenue level by 2026. In this scenario, institutions experience the socalled cohort effect from a year of reduced enrollment - the class is permanently smaller, affecting revenue for the duration of the cohort's time at the university.

- Pessimistic scenario: Net tuition revenue losses in 2020 are $20 \%$ more severe than the losses in the realistic scenario due to tuition discounting and institutions' inability to raise tuition once demand resumes, such that net tuition revenue exhibits a slower recovery than enrollment.

\section{- Appropriations}

- We assume that each institution's annual revenue from state and local appropriations follows the state-level projections calculated in Section IV. Theoretically, states could reduce some institutions' funding more than others' funding, though we do not believe this practice to be commonplace.

- Of note is the fact that SHEEO data indicate that total state appropriations for fiscal year 2019 were $\$ 112$ billion per year, but the total across all institutions in IPEDS is about $\$ 90$ billion per year, so our appropriation losses from IPEDS will be lower than those estimated in Section IV. This is because some of the state and local funding for higher education does not flow to public colleges and universities, but rather it flows to students. An extreme example of such a system is Colorado's Opportunity Fund, which is essentially a voucher system. 


\section{- Auxiliary revenue}

- For 2020, we assume that any auxiliary revenue losses are reflected in the year-over-year changes in key metrics of economic activity at the local level. As described in Section III, we consider SafeGraph's anonymized mobile phone "check-ins" data in the area marked by the boundaries of a given college or university and Womply's anonymized consumer spending data (overall and at merchants marked as "higher education") as indicators of economic activity related to generation of auxiliary revenue. To approximate the beginning of the fall semester, we use year-over-year changes from August-October 2020 relative to August-October 2019.

- To calculate our estimate of the auxiliary revenue change in 2020, we take a straight average of the following metrics:

- Year-over-year changes in visitors at the institution level, filled in with county or state figures if unavailable (SafeGraph);

- Year-over-year changes in visits at the institution level, filled in with county or state figures if unavailable (SafeGraph);

- Year-over-year changes in median length of visit at the institution level, filled in with county figures if missing (SafeGraph);

- Year-over-year changes in overall consumer spending in the institution's county, filled in with state figures if missing (Womply);

- Year-over-year changes in consumer spending at higher education merchants in the institution's state (Womply);

○ For fiscal years 2021-2025, auxiliary revenue is assumed to exhibit a linear recovery back to the 2019 value by 2026 .

Once we implement the previous assumptions, we can calculate losses attributable to one of the three main revenue categories for each institution, as well as the total revenue loss across the three categories for the three scenarios. Recall that state and local appropriations and auxiliary revenue follow the same path in each scenario, such that assumptions on net tuition revenue drive the need for three different overall totals. 


\section{Annual Revenue Losses}

Projected annual revenue losses from different revenue categories were calculated in Table 2 by adding up losses for those institutions that experience them. In other words, if an institution experiences a gain in a particular category, that value is set to 0 and does not enter our totals. As this paper is focused on identifying categories of revenue and types of institutions where revenue losses are concentrated, we consider that to be an appropriate choice. As shown in Table 2, and consistent with our projections in Section IV, losses from state and local appropriations are currently moderate but are expected to increase substantially over the next five years. On the other hand, the impact on net tuition revenue is projected to be more severe this year than in the future, assuming the recovery continues along its current path. Institutions are projected to lose some $\$ 13.6$ billion to $\$ 16.3$ billion from net tuition revenue in 2020 alone, and about $\$ 11.6$ billion from auxiliary revenue - nearly as much as from state and local appropriations over the next five years.

\section{Cumulative Revenue Losses}

The remainder of this paper, we discuss cumulative revenue losses (over 2020-2025) for individual revenue categories and overall. The last column of Table 2 and Figure 5 show that institutions stand to lose about $\$ 13.6$ billion in net tuition revenue under the optimistic scenario, $\$ 48$ billion under the realistic scenario, and $\$ 57.3$ billion under the pessimistic scenario. Combined with losses of about $\$ 17.2$ billion from state and local appropriations and \$40.6 billion from auxiliary revenue, the higher education sector is potentially facing total six-year losses of between $\$ 71$ billion and $\$ 115$ billion - a sobering sum. We emphasize that: a) revenue losses are estimated to be weighing heavily on institutions already, primarily in the form of losses from net tuition and auxiliary revenue streams; however, $b$ ) losses from state and local funding are projected to ramp up over the next five years and provide additional challenges for public universities.

Table 3 and Figure 6 illustrate the differing effects of the pandemic across the different sectors in higher education. By design, the entire revenue loss from state and local appropriations is borne by public colleges and universities, for a total of about $\$ 17.1$ billion of the six-year period and about $19 \%$ of 2019 revenue from state and local appropriations. For all sectors, auxiliary revenue losses represent the single largest percentage loss, with for-profit colleges faring particularly poorly (cumulative losses equal to a year's worth of 2019 auxiliary revenue) compared with public and private non-profit colleges (cumulative losses of about $80 \%-85 \%$ of 2019 auxiliary revenue). Net tuition revenue losses tend to 
affect all types of institutions similarly, though private (and particularly private for-profit) institutions fare about $25 \%$ worse than public institutions.

\section{Losses by Institution Type}

Next, we consider how the incidence of revenue losses differs by type of institution, as displayed in Table 4 and Figure 7; for simplicity, we provide estimates based on the realistic scenario only for this portion of the analysis. We calculate the share of institutions of various types that are projected to experience one of the following under the realistic scenario assumptions:

- No loss of revenue (or gain);

- Cumulative six-year revenue loss of $0 \%-25 \%$ of 2019 revenue;

- Cumulative six-year revenue loss of $25 \%-50 \%$ of 2019 revenue; and

- Cumulative six-year revenue loss of $>50 \%$ of 2019 revenue.

As can be seen in Table 4, most public and private nonprofit institutions are projected to experience moderate- to severe-financial distress ( $77 \%-88 \%$ of institutions) under the realistic scenario, with relatively few institutions experiencing no losses at all (7\%-12\% of institutions) or severe losses in total revenue as a share of 2019 total revenue. On the other hand, the for-profit market exhibits a bifurcated distribution: Most institutions experience either no revenue losses (40\% of institutions) or severe losses (36\% of institutions). Figure 7 confirms this interpretation by comparing institutions that are projected to fare reasonably well ( $<25 \%$ cumulative revenue losses) in green with institutions that are projected to fare particularly poorly ( $>50 \%$ cumulative revenue losses) in red.

Continuing through the institution categories, Table 4 shows that large institutions - those educating 1,000 or more students — are more likely to experience moderate cumulative six-year losses, while smaller institutions are more likely to see projected losses greater than half of 2019 revenue $(27 \%$ of institutions). Finally, we find that HBCUs will also bear a disproportionate burden, with nearly half of all institutions projected to have $25 \%$ or more cumulative six-year revenue losses. Rural institutions are faring relatively well; Figure 7 shows that about $78 \%$ of institutions have modest losses (cumulative losses $<25 \%$ of 2019 revenue), with about $10 \%$ of institutions experiencing the most severe distress (cumulative losses $>50 \%$ of 2019 revenue). ${ }^{7}$ These effects are driven in part by decisions by many

\footnotetext{
${ }^{7}$ As a check of our results, in Table 1A in the Appendix, we calculate the equivalent percentages as the share of students instead of institutions. The patterns we identified in Table 4 still hold, but some are amplified. The share of students attending
} 
HBCUs to remain primarily online for the 2020-2021 academic year, while many small rural institutions operated close to business as usual.

\section{Discussion}

Consistent with anecdotes from around the higher education landscape, institutions are already experiencing significant fiscal distress. Our projections show that some institutions - particularly public colleges and universities and HBCUs - will likely face additional revenue losses in the next five years. Our paper contributes to the conversation on the fiscal viability of institutions of higher education by projecting losses in state and local appropriations, net tuition revenue, and auxiliary revenue across institution types and sectors to inform higher education leaders and policymakers interested in relieving the financial pressure on institutions.

We project that public colleges and universities are likely to experience revenue losses from state and local appropriations about half of the magnitude of losses during and following the Great Recession, on the order of $\$ 17$ billion to $\$ 30$ billion over the period 2020-2025. However, appropriations represent a relatively small fraction of the cumulative revenue losses from the three main revenue categories, which we estimate to be $\$ 70$ billion to $\$ 115$ billion over the next five years. The extent of revenue losses depends crucially on assumptions about the pace of the economic recovery, and we urge future researchers to explore the range of possible revenue loss values under more complex sets of assumptions. In particular, the medium- to long-term financial situation for institutions will become much clearer once spring 2022 (and especially fall 2022) enrollment numbers become available; our analysis will merit a review in light of that additional information.

We emphasize that the focus of this paper has been entirely on the revenue side, whereas it is possible that expenses have also changed (in either direction) as a result of the pandemic. Some expenses were likely to be temporary (e.g., selective room and board refunds, COVID-19 testing) and others - especially related to new technology to enable hybrid and virtual learning — may be permanent. Our cumulative revenue loss figures might therefore translate into even higher budget shortfalls if our assumption of constant expenses turns out to be untrue.

institutions with no losses is only $5 \%$, while the share of institutions with no losses is $20 \%$. On the other hand, the share of students at institutions with severe losses is smaller than the share of institutions with severe losses. Generally speaking, this means that small institutions are projected to perform either very poorly or very well, and mid-to-large institutions (where most students attend) are projected to have mild to moderate losses. 
Our projections reveal that most public colleges, private nonprofit colleges, and rural colleges will experience moderate cumulative losses (no loss, loss $<25 \%$ of 2019 revenue) over the next five years, while revenue losses will be the most severe ( $>50 \%$ of 2019 revenue) among institutions with fewer than 1,000 students, HBCUs, and certain for-profit colleges as a result of the COVID-19 pandemic. But what might these revenue losses ultimately mean for the students and staff that institutions of higher education serve? We expect at least some colleges and universities to be in situations precarious enough that obtaining debt to weather the crisis will not be possible, so we anticipate increased consolidation activity in the years to come, particularly among smaller institutions that depend critically on net tuition revenue and revenue from auxiliary enterprises. Although prior research has shown that private nonprofit colleges in particular have a low likelihood of closing during challenging economic times (Tarrant et al., 2018), we still expect the rate of college closures to tick up somewhat over the next several years.

While colleges have historically taken steps to increase revenues in response to financial challenges, we anticipate that cost-cutting measures will be the more typical response to pandemicassociated financial challenges. Many colleges are in the process of reviewing academic programs to identify ones that serve few students and generate operating losses, and institutions will likely be slow to fill positions that were vacated due to the pandemic.

The important consideration for administrators and policymakers when plotting the long-term trajectory of programs and institutions is whether these entities would be viable in the long run in the absence of pandemic constraints. Some programs, and even institutions, were likely on a trend toward mergers or elimination prior to the pandemic; if an entity truly isn't adding value commensurate with its costs, then it is in society's overall interest that it be contracted. However, programs, positions, or institutions that face elimination only due to the temporary financial constraints imposed by the pandemic must be supported and preserved. We would make this general argument about any enterprise, but given the important role of higher education as an economic engine of both the present and future, it is particularly important that policymakers make decisive and thoughtful action in this sphere. The methodology implemented in this paper can help inform those actions. 


\section{References}

Alexander, F. K., Harnisch, T., Hurley, D., and Moran, R. (2010). “Maintenance of effort”: An evolving federal-state policy approach to ensuring college affordability. Washington, DC: American Association of State Colleges and Universities.

Allen, D., and Wolniak, G. C. (2019). "Exploring the effects of tuition increases on racial/ethnic diversity at public colleges and universities." Research in Higher Education, 60(1), 18-43.

American Council on Education (2014). Understanding college and university endowments. Washington, DC: American Council on Education.

Anderson, G. (2020, April 24). "Pandemic hits college sports." Inside Higher Ed. Retrieved from https://www.insidehighered.com/news/2020/04/24/financial-crisis-related-coronavirus-hits-athleticdepartments.

Applegate, J. (2021, March 16). "Annual Grapevine compilation of state fiscal support for higher education results for fiscal year 2021." Illinois State University. Retrieved from https://education.illinoisstate.edu/downloads/grapevine/grapevine pr fy21.pdf.

Archibald, R. B., and Feldman, D. H. (2008). "Explaining increases in higher education costs." The Journal of Higher Education, 79(3), 268-295.

Baer, J., and Martel, M. (2020). Fall 2020 international student enrollment snapshot. New York: Institute of International Education.

Barr, A., and Turner, S. E. (2013). "Expanding enrollments and contracting state budgets: The effect of the Great Recession on higher education." The ANNALS of the American Academy of Political and Social Science, 650(1), 168-193.

Bauer-Wolf, J. (2020, September 14). "College tuition benchmark posts big drop in August.” Education Dive. Retrieved from https://www.educationdive.com/news/college-tuition-benchmark-posts-bigdrop-in-august/585171/.

Baum, S., Hill, C. B., and Schwartz, E. (2018). College and university endowments: In the public interest? New York, NY: Ithaka S+R.

Baum, S., and Lee, V. (2018). Understanding endowments. Washington, DC: Urban Institute.

Bauman, D. (2021, February 5). “A brutal tally: Higher ed lost 650,000 jobs last year.” The Chronicle of Higher Education. Retrieved from https:/www.chronicle.com/article/a-brutal-tally-higher-ed-lost650-000-jobs-last-year.

Baumol, W. J. (1967). "Macroeconomics of unbalanced growth: The anatomy of urban crisis." American Economic Review, 57(3), 415-426. 
Berkowitz, S. (2021, January 25). "NCAA revenue for 2020 down 50\% due to pandemic-forced cancellation of basketball tournament." USA Today. Retrieved from https://www.usatoday.com/story/sports/college/2021/01/25/ncaa-revenue-decrease-due-to-nobasketball-tournament/6699352002/.

Bowen, H. R. (1980). The costs of higher education: How much do colleges and universities spend per student and how much should they spend? San Francisco, CA: Jossey-Bass.

Chakrabarti, R., Gorton, N., and Lovenheim, M. F. (2020). State investment in higher education: Effects on human capital formation, student debt, and long-term financial outcomes of students. New York, NY: Federal Reserve Bank of New York Staff Reports 941.

Chetty, R., Friedman, J., Saez, E., Turner, N., and Yagan, D. (2017). Mobility report cards: The role of colleges in intergenerational mobility. Cambridge, MA: National Bureau of Economic Research Working Paper 23618.

Commonfund Institute (2019). Commonfund higher education price index. Wilton, CT: Commonfund Institute.

Curs, B. R., and Jaquette, O. (2017). "Crowded out? The effect of nonresident enrollment on resident access to public research universities.” Educational Evaluation and Policy Analysis, 39(4), 644669.

Delaney, J. A., and Doyle, W. R. (2011). "State spending on higher education: Testing the balance wheel over time." Journal of Education Finance, 36(4), 343-368.

Delaney, J. A., and Doyle, W. R. (2018). "Patterns and volatility in state funding for higher education, 1951-2006.” Teachers College Record, 120(6), 1-42.

Deming, D. J., Goldin, C., Katz, L. F., and Yuchtman, N. (2015). "Can online education bend the higher education cost curve?” American Economic Review, 105(5), 2015.

Deming, D. J., and Walters, C. R. (2017). The impact of price caps and spending cuts on U.S. postsecondary attainment. Cambridge, MA: National Bureau of Economic Research Working Paper 23736.

Denison, D., Fowles, J., and Moody, M. J. (2014). "Borrowing for college: A comparison of long-term debt financing between public and private, nonprofit institutions of higher education." Public Budgeting \& Finance, 34(2), 84-104.

Doyle, W. R., and Skinner, B. T. (2017). "Does postsecondary education result in civic benefits?” The Journal of Higher Education, 88(6), 863-893.

Greene, J. (2020, May 5). 'University of Michigan's health system plans furloughs, delays new hospital as it battles budget deficit." Crain's Detroit Business. Retrieved from 


\section{https://www.crainsdetroit.com/health-care/university-michigans-health-system-plans-furloughs-}

delays-new-hospital-it-battles.

Hout, M. (2012). "Social and economic returns to college education in the United States." Annual Review of Sociology, 38, 379-400.

Hovey, H. A. (1999). State spending for higher education in the next decade: The battle to sustain current support. San Jose, CA: California State Policy Research, Inc.

Jaquette, O., and Curs, B. R. (2015). "Creating the out-of-state university: Do public universities increase nonresident freshman enrollment in response to declining state appropriations?" Research in Higher Education, 56(6), 535-565.

Jaquette, O., Curs, B. R., and Posselt, J. R. (2016). "Tuition rich, mission poor: Nonresident enrollment growth and the socioeconomic and racial composition of public research universities." Journal of Higher Education, 87(5), 635-673.

Kelchen, R. (2018). Higher education accountability. Baltimore, MD: Johns Hopkins University Press.

Kelchen, R. (2019). “Merging data to facilitate analyses." New Directions in Institutional Research, 181, 59-72.

Kelchen, R., Ortagus, J., Baker, D., and Rosinger, K. (2020). Trends in state funding for public higher education. InformEd States.

Kelchen, R., and Pingel, S. (2018). Postsecondary tuition capping and freezing. Denver, CO: Education Commission of the States.

Laderman, S., and Tandberg, D. A. (2021). SHEEO analysis of fiscal year 2021 state funding for higher education. Boulder, CO: State Higher Education Executive Officers Association.

Laderman, S., and Weeden, D. (2020). State higher education finance: FY 2019. Boulder, CO: State Higher Education Executive Officers Association.

Lederman, D. (2020, July 10). "COVID-19's forceful financial hit: A survey of business officers." Inside Higher Ed. Retrieved from https://www.insidehighered.com/news/survey/covid-19s-forcefulfinancial-hit-survey-business-officers.

Ma, J., Baum, S., Pender, M., and Libassi, C. (2019). Trends in college pricing 2019. New York, NY: College Board.

McClure, K. R., Ryder, A. J., and DeVita, J. M. (2017). "Public-private partnerships in college student housing: Lessons from three institutions." Journal of College \& University Student Housing, 43(2), 72-93.

National Association of College and University Budget Officers (2020a). Financial accounting and reporting manual for higher education. Retrieved from http://efarm.nacubo.org/farm?qr=1. 
National Association of College and University Budget Officers (2020b, February 4). Public NTSE tables. Retrieved from https://www.nacubo.org/Research/2020/Public-NTSE-Tables.

National Student Clearinghouse (2020). Fall 2020 current term enrollment estimates. Retrieved from https://nscresearchcenter.org/current-term-enrollment-estimates/.

Open Campus (2020, April 6). What's happening with state budgets and higher ed. Retrieved from https://www.opencampusmedia.org/2020/04/06/whats-happening-with-state-budgets-and-highereducation/.

Oreopoulos, P., and Petronijevic, U. (2013). "Making college worth it: A review of the returns to higher education." The Future of Children, 23(1), 41-65.

Ortagus, J. C. (2020). What we know about the cost and quality of online education. Washington, DC: Third Way.

Ost, B., Pan, W., and Webber, D. A. (2018). "The returns to college persistence for marginal students: Regression discontinuity evidence from university dismissal policies." Journal of Labor Economics, 36(3), 779-805.

Redd, K. (2020). 2019 NACUBO-TIAA study of endowments. Washington, DC: National Association of College and University Budget Officers.

Seltzer, R. (2020, August 7). "Housing developer pressured universities on fall plans." Inside Higher Ed. Retrieved from https://www.insidehighered.com/news/2020/08/07/housing-developer-remindeduniversities-about-project-debt-they-mulled-fall-plans.

Storms, K., Miller, S. E., and Hall, B. (2017). "P4: The role of planning in successful public-private partnerships (P3s)." Planning for Higher Education Journal, 45(3), 1-13.

Tarrant, M., Bray, N., and Katsinas, S. (2018). "The invisible colleges revisited: An empirical review." The Journal of Higher Education, 89(3), 341-367.

USA Today (n.d.). "NCAA Finances." Retrieved from https://sports.usatoday.com/ncaa/finances/.

Webber, D. A. (2016). "Are college costs worth it? How ability, major, and debt affect the returns to schooling." Economics of Education Review, 53, 296-310.

Webber, D. A. (2017). "State divestment and tuition at public institutions." Economics of Education Review, 60, 1-4.

Webber, D. A., and Ehrenberg, R. A. (2010). "Do expenditures other than instructional expenditures affect graduation and persistence rates in American higher education? Economics of Education Review, 29(6), 947-958. 
Williamson, R. (2020, September 15). "P3 college housing down 8\% in September, developer says." The Bond Buyer. Retrieved from https://www.bondbuyer.com/news/p3-college-housing-down-8-inseptember-developer-says.

Witsil, F. (2020, April 20). "University of Michigan makes cuts, forecasts losses of up to $\$ 1$ billion." Detroit Free Press. Retrieved from https://www.freep.com/story/news/education/2020/04/20/university-michigan-makes-cuts-stemloss-schlissel/5166574002/. 
Table 1: Sources of Revenue for Nonprofit Colleges and Universities

\begin{tabular}{|c|c|c|c|c|}
\hline \multirow{2}{*}{ Revenue (S billion) } & \multicolumn{2}{|c|}{ Public } & \multicolumn{2}{|c|}{ Private Non-Profit } \\
\hline & $\$$ & $\%$ & $\$$ & $\%$ \\
\hline Total revenue & 418.7 & $100 \%$ & 243.4 & $100 \%$ \\
\hline Net tuition revenue & 82.9 & $20 \%$ & 78.6 & $32 \%$ \\
\hline Federal revenue & 54.8 & $13 \%$ & 20.5 & $8 \%$ \\
\hline State revenue & 90.2 & $22 \%$ & 1.9 & $1 \%$ \\
\hline Local revenue & 29.3 & $7 \%$ & 0.6 & $0 \%$ \\
\hline Private gifts and grants & 22.2 & $5 \%$ & 31.1 & $13 \%$ \\
\hline Auxiliary revenue & 29.4 & $7 \%$ & 28.3 & $12 \%$ \\
\hline Hospital revenue & 53.9 & $13 \%$ & 8.6 & $4 \%$ \\
\hline Other revenue & 55.9 & $13 \%$ & 73.8 & $30 \%$ \\
\hline
\end{tabular}

Source: Authors' calculations based on data from the U.S. Department of Education's Integrated Postsecondary Education Data System (IPEDS) 
Table 2: Projected Revenue Loss, by Revenue Source and Year

\begin{tabular}{|c|c|c|c|c|c|c|c|}
\hline Revenue Loss ( S billion) & 2020 & 2021 & 2022 & 2023 & 2024 & 2025 & Total \\
\hline \multicolumn{8}{|l|}{ Net Tuition Revenue } \\
\hline Optimistic Scenario & 13.6 & 0.0 & 0.0 & 0.0 & 0.0 & 0.0 & 13.6 \\
\hline Realistic Scenario & 13.6 & 11.4 & 9.1 & 6.9 & 4.6 & 2.4 & 48.0 \\
\hline Pessimistic Scenario & 16.3 & 13.6 & 10.9 & 8.2 & 5.5 & 2.8 & 57.3 \\
\hline $\begin{array}{l}\text { State \& Local } \\
\text { Appropriations }\end{array}$ & 1.0 & 1.7 & 3.5 & 4.4 & 3.6 & 3.0 & $\begin{array}{c}17.2 \\
-\end{array}$ \\
\hline Auxiliary Revenue & 11.6 & 9.7 & 7.7 & 5.8 & 3.9 & 2.0 & 40.6 \\
\hline \multicolumn{8}{|l|}{ Total } \\
\hline Optimistic Scenario & 26.2 & 11.3 & 11.2 & 10.2 & 7.5 & 5.0 & 71.4 \\
\hline Realistic Scenario & 26.2 & 22.7 & 20.3 & 17.1 & 12.1 & 7.3 & 105.8 \\
\hline Pessimistic Scenario & 28.9 & 24.9 & 22.1 & 18.4 & 13.0 & 7.8 & 115.1 \\
\hline
\end{tabular}

Notes: The optimistic scenario assumes a net tuition revenue loss in 2020 equal to the Title IV funding change and no losses in years 2021-2025. The realistic scenario assumes a net tuition revenue loss in 2020 equal to the Title IV funding change, then linear recovery over the following five years back to 2019 net tuition revenue level by 2026 . The pessimistic scenario assumes net tuition revenue losses in each year that are $20 \%$ more severe than the losses in the realistic scenario.

Source: Authors' calculations based on data from the U.S. Department of Education's Integrated Postsecondary Education Data System (IPEDS) (college finances), National Association of State Budget Officers (NASBO) (revenue), SafeGraph (consumer mobility), State Higher Education Executive Officers Association (SHEEO) (appropriations), and Womply (consumer spending) 
Table 3: Projected Six-Year Cumulative Revenue Loss, by Revenue Type and Sector

\begin{tabular}{|c|c|c|c|c|c|c|}
\hline Revenue Loss (S billion) & \multicolumn{2}{|c|}{ Public } & \multicolumn{2}{|c|}{ Private Non-Profit } & \multicolumn{2}{|c|}{ For-Profit } \\
\hline & & $\begin{array}{l}\% \text { of } \\
2019\end{array}$ & & $\begin{array}{l}\% \text { of } \\
2019\end{array}$ & & $\begin{array}{l}\% \text { of } \\
2019\end{array}$ \\
\hline & $\$ B N$ & Value & $\$ B N$ & Value & $\$ B N$ & Value \\
\hline \multicolumn{7}{|l|}{ Net tuition revenue } \\
\hline Optimistic Scenario & 7.6 & $9 \%$ & 4.3 & $11 \%$ & 1.7 & $11 \%$ \\
\hline Realistic Scenario & 26.7 & $32 \%$ & 15.2 & $39 \%$ & 6.1 & $41 \%$ \\
\hline Pessimistic Scenario & 32.0 & $39 \%$ & 18.2 & $47 \%$ & 7.2 & $49 \%$ \\
\hline $\begin{array}{l}\text { State \& Local } \\
\text { Appropriations }\end{array}$ & 17.1 & $19 \%$ & - & $\mathrm{N} / \mathrm{A}$ & - & $\mathrm{N} / \mathrm{A}$ \\
\hline Auxiliary Revenue & 25.1 & $85 \%$ & 15.4 & $83 \%$ & 0.1 & $102 \%$ \\
\hline \multicolumn{7}{|l|}{$\underline{\text { Total }}$} \\
\hline Optimistic Scenario & 49.8 & $12 \%$ & 19.8 & $8 \%$ & 1.8 & $10 \%$ \\
\hline Realistic Scenario & 68.9 & $17 \%$ & 30.6 & $13 \%$ & 6.2 & $35 \%$ \\
\hline Pessimistic Scenario & 74.2 & $19 \%$ & 33.6 & $14 \%$ & 7.4 & $41 \%$ \\
\hline
\end{tabular}

Notes: Cumulative revenues for each revenue source are calculated as the sum of annual revenue losses for 2020 through 2025 fiscal years. The shares are calculated as the cumulative loss for the revenue source over 2020 through 2025 fiscal years divided by fiscal year 2019 revenue for that revenue source. The optimistic scenario assumes a net tuition revenue loss in 2020 equal to the Title IV funding change and no losses in years 2021-2025. The realistic scenario assumes a net tuition revenue loss in 2020 equal to the Title IV funding change, then linear recovery over the following five years back to 2019 net tuition revenue level by 2026 . The pessimistic scenario assumes net tuition revenue losses in each year that are $20 \%$ more severe than the losses in the realistic scenario.

Source: Authors' calculations based on data from IPEDS (college finances), NASBO (revenue), SafeGraph (consumer mobility), SHEEO (appropriations), and Womply (consumer spending) 


\section{Table 4: Incidence of Financial Distress, by Institution Type}

\begin{tabular}{|c|c|c|c|c|c|}
\hline \multirow[b]{2}{*}{ Institution Type } & \multirow[b]{2}{*}{$\begin{array}{c}\# \\
\text { Institutions } \\
\end{array}$} & \multicolumn{4}{|c|}{ Cumulative 6-Year Revenue Loss } \\
\hline & & No Loss & $\begin{array}{c}\text { Loss }<25 \% \\
\text { of } 2019 \text { Revenue }\end{array}$ & $\begin{array}{c}25 \%<=\text { Loss }<50 \% \\
\text { of } 2019 \text { Revenue }\end{array}$ & $\begin{array}{c}\text { Loss }>=50 \% \\
\text { of } 2019 \text { Revenue }\end{array}$ \\
\hline Two-Year Public & 1,176 & $7 \%$ & $64 \%$ & $21 \%$ & $8 \%$ \\
\hline Four-Year Public & 784 & $5 \%$ & $62 \%$ & $25 \%$ & $7 \%$ \\
\hline Four-Year Non-Profit & 1,615 & $12 \%$ & $60 \%$ & $18 \%$ & $11 \%$ \\
\hline For-Profit & 2,076 & $40 \%$ & $14 \%$ & $11 \%$ & $36 \%$ \\
\hline Small ( $<1000$ students) & 2,913 & $33 \%$ & $26 \%$ & $13 \%$ & $27 \%$ \\
\hline Large ( $>1000$ students) & 2,738 & $6 \%$ & $62 \%$ & $21 \%$ & $10 \%$ \\
\hline $\mathrm{HBCU}$ & 105 & $5 \%$ & $48 \%$ & $24 \%$ & $24 \%$ \\
\hline Rural & 497 & $13 \%$ & $61 \%$ & $16 \%$ & $9 \%$ \\
\hline Total & 5,651 & $20 \%$ & $44 \%$ & $17 \%$ & $19 \%$ \\
\hline
\end{tabular}

Notes: This table displays the share of institutions in each category with different thresholds of cumulative revenue loss from net tuition revenue, appropriations, and auxiliary revenue (sum of total annual revenue losses for 2020 through 2025 fiscal years divided by fiscal year 2019 total revenue). All estimates produced under the assumptions of the realistic scenario - a net tuition revenue loss in 2020 equal to the Title IV funding change, then linear recovery over the following five years back to 2019 net tuition revenue level by 2026. HBCU = Historically Black College or University

Source: Authors' calculations based on data from IPEDS (college finances), NASBO (revenue), SafeGraph (consumer mobility), SHEEO (appropriations), and Womply (consumer spending) 


\section{Figure 1: Revenues and Higher Education Appropriations During the Great Recession}

\section{(Select States)}

(A)

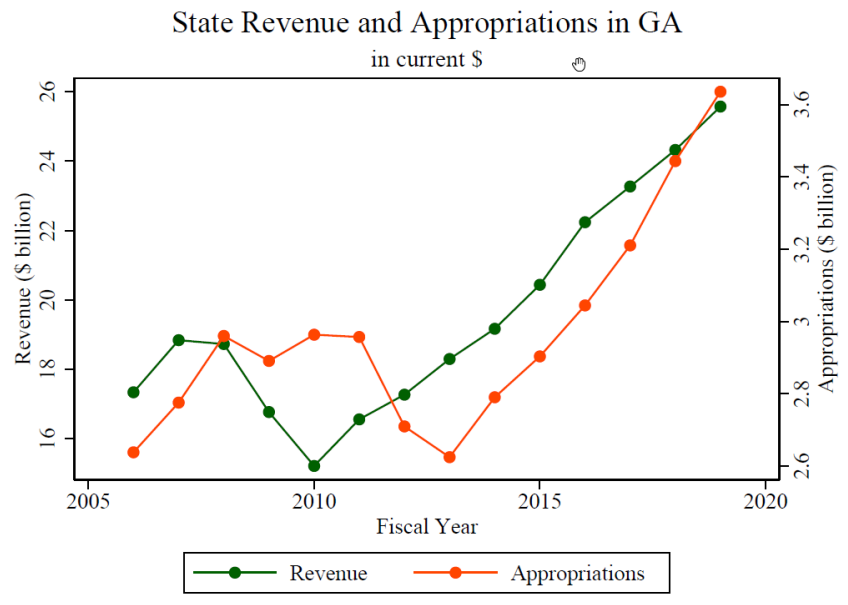

(C)

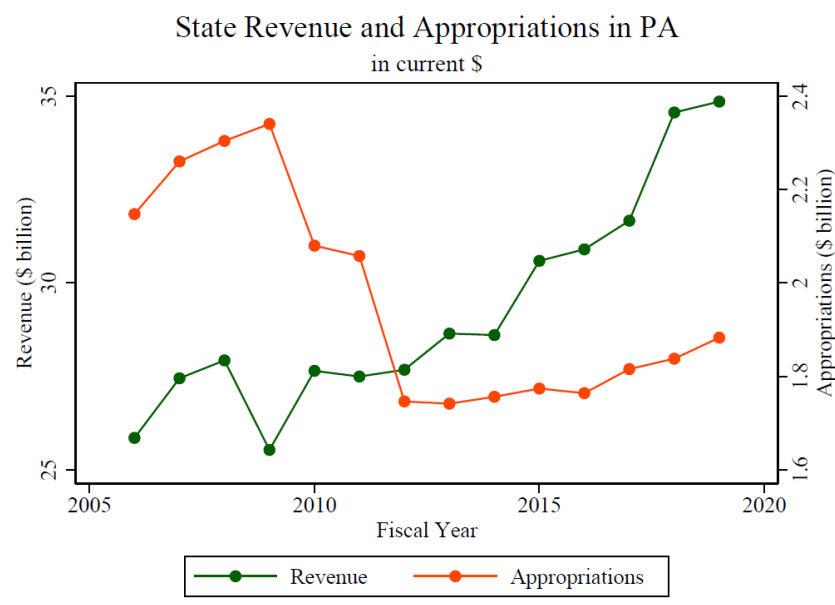

(B)

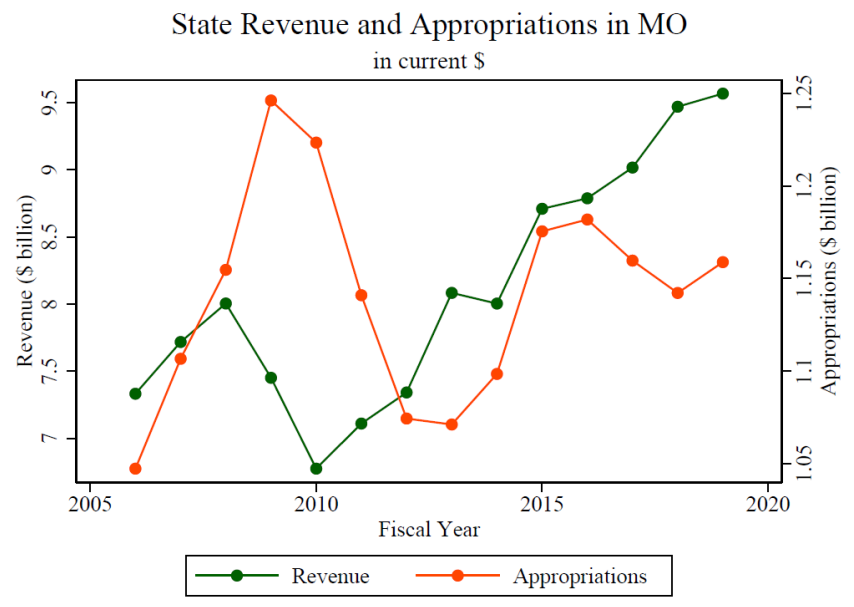

(D)

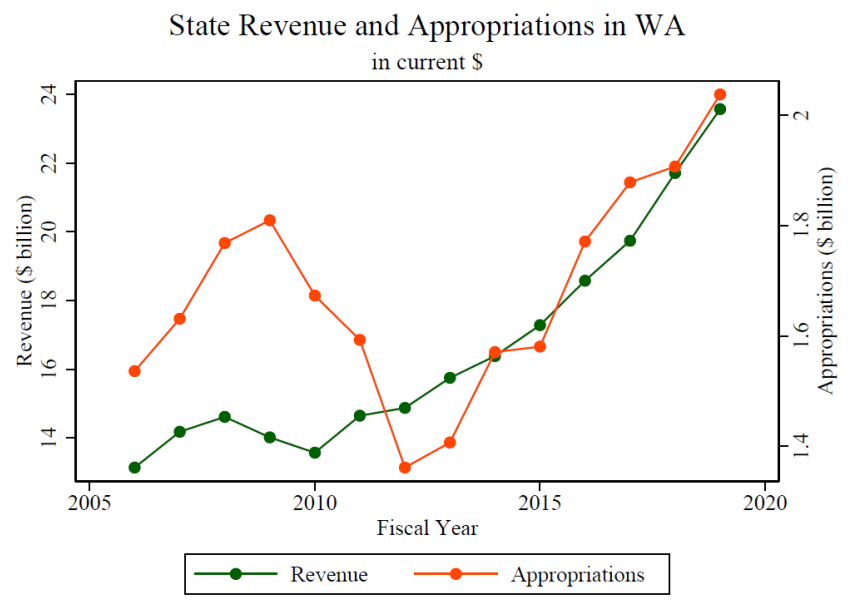

Source: Authors' calculations based on data from NASBO (revenue) and SHEEO (appropriations) 
Figure 2: State General Revenue (Real) Changes Relative to Baseline Year
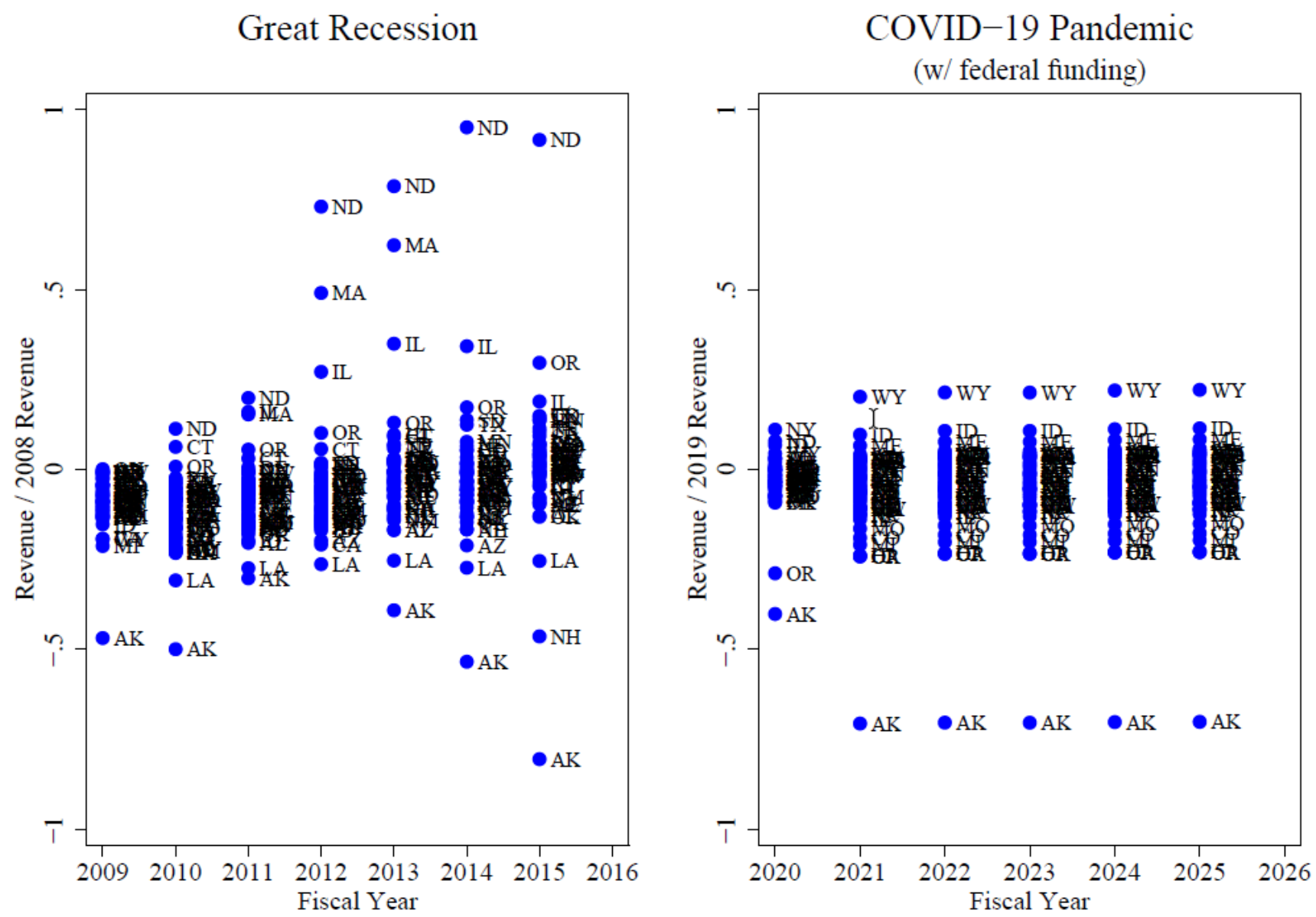

Notes: Revenue values are in 2019 dollars. Each dot represents one state's ratio of a particular year's revenue in 2019 dollars relative to the baseline year's revenue in 2019 dollars.

Source: Authors' calculations based on data from NASBO 
Figure 3: Higher Education Appropriation (Real) Changes Relative to Baseline Year
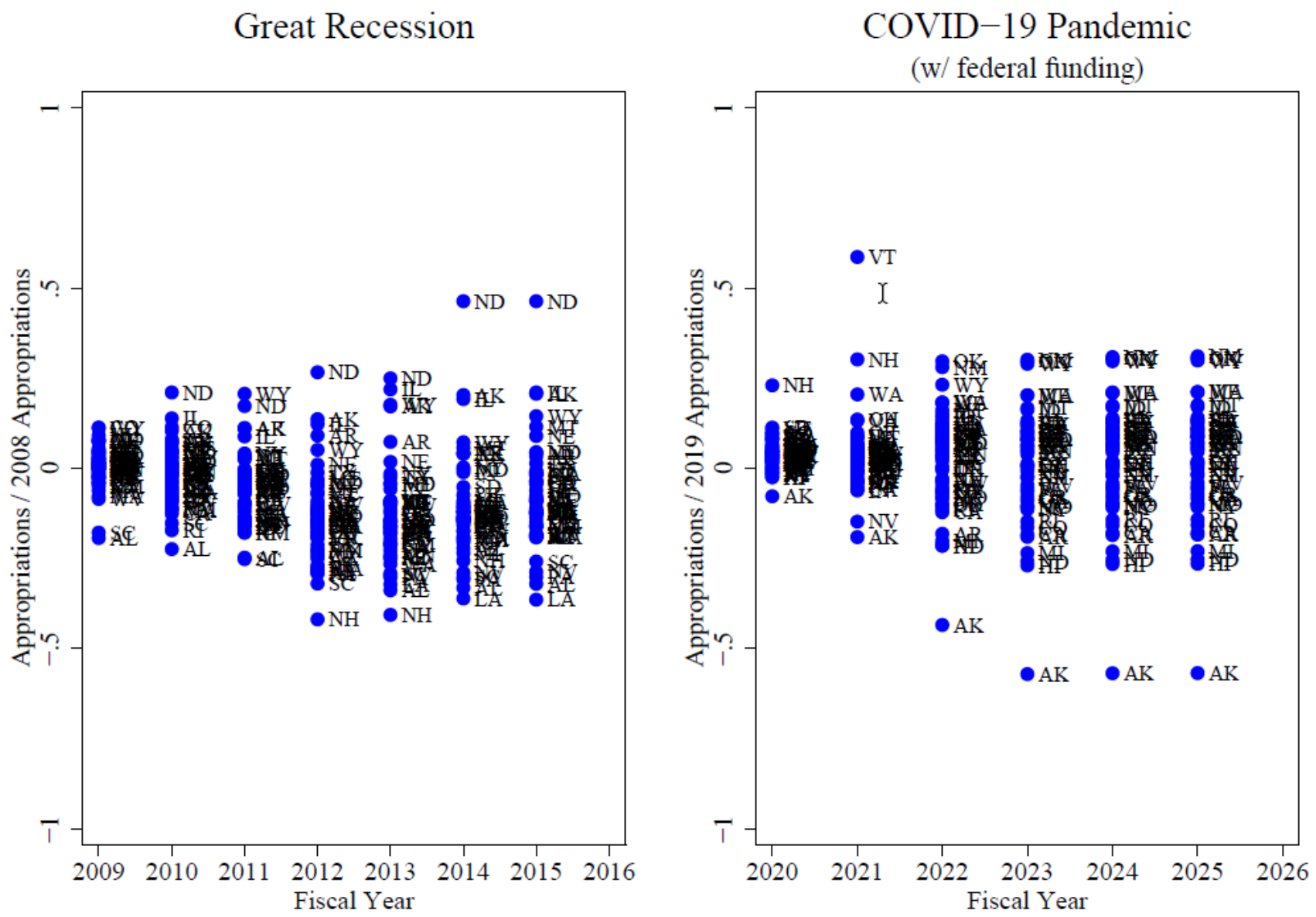

Notes: Revenue values are in 2019 dollars. Each dot represents one state's ratio of a particular year's state appropriations in 2019 dollars relative to the baseline year's state appropriations in 2019 dollars.

Source: Authors' calculations based on data from SHEEO 
Figure 4: States with Appropriation Declines Relative to Baseline Year

Number of States with Declines in Appropriations
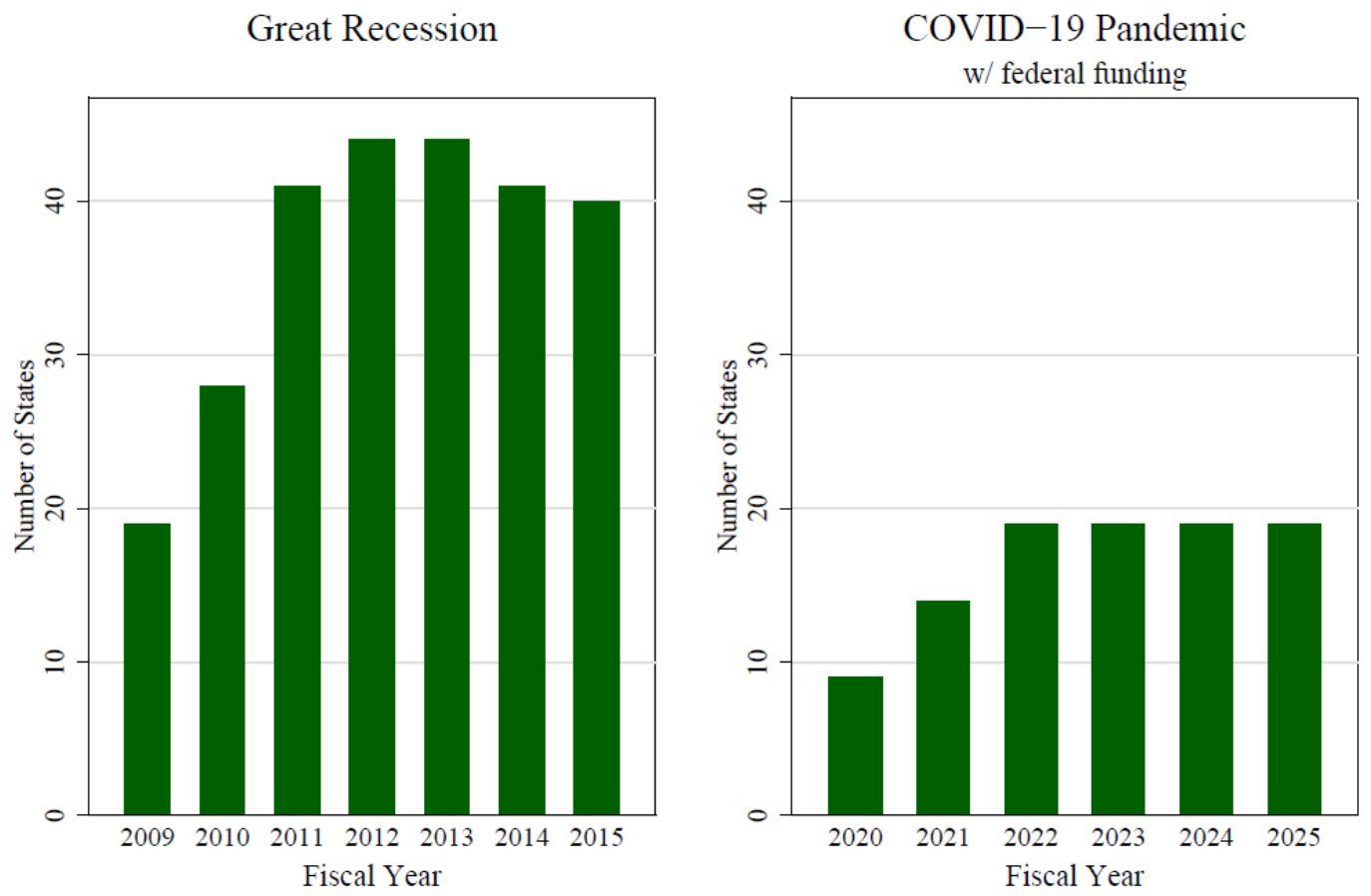

Total of State \& Local Appropriation Declines in $2019 \$$
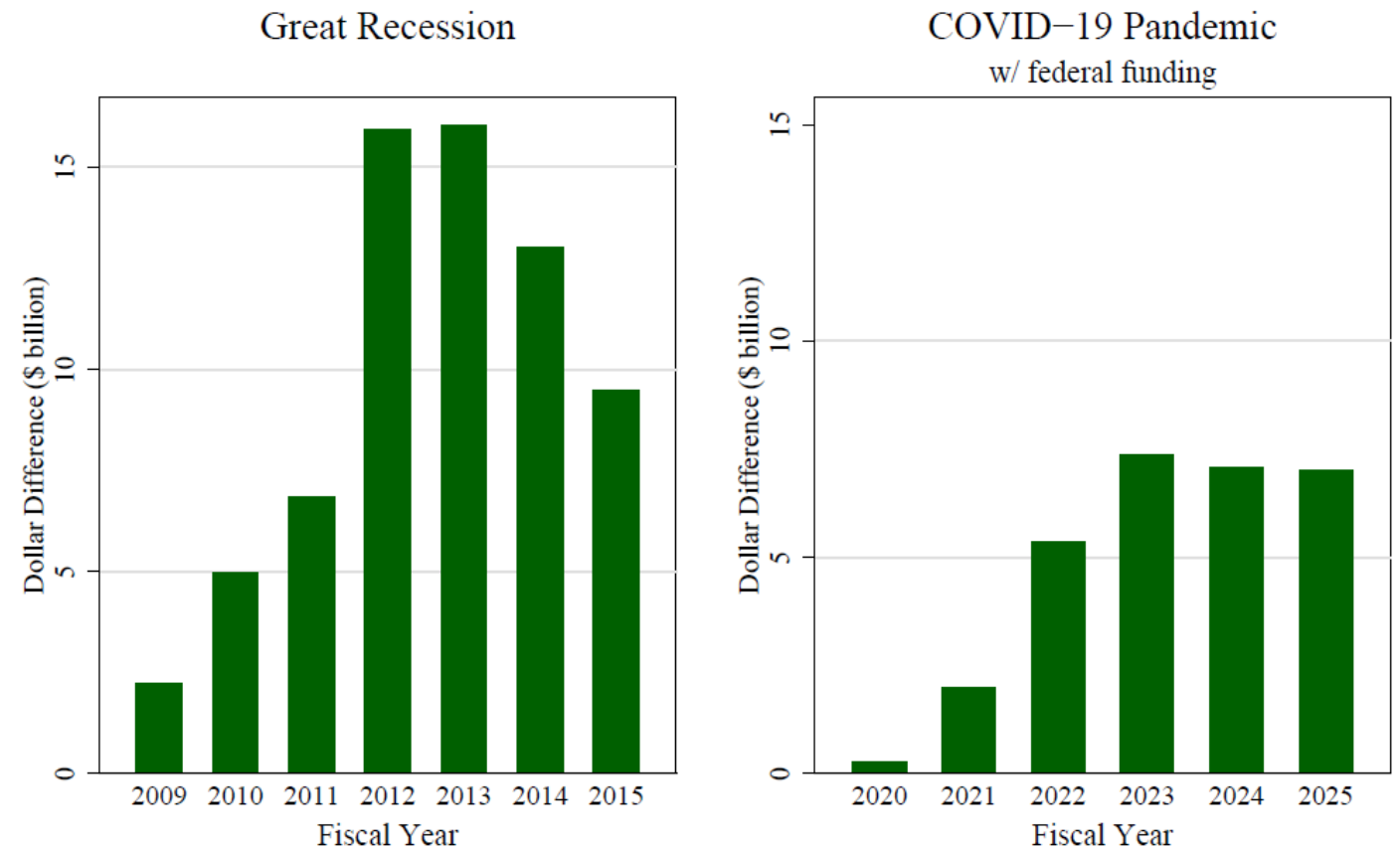

Source: Authors' calculations based on data from NASBO (revenue) and SHEEO (appropriations) 
Figure 5: Projected Cumulative Six-Year Revenue Loss, by Revenue Source

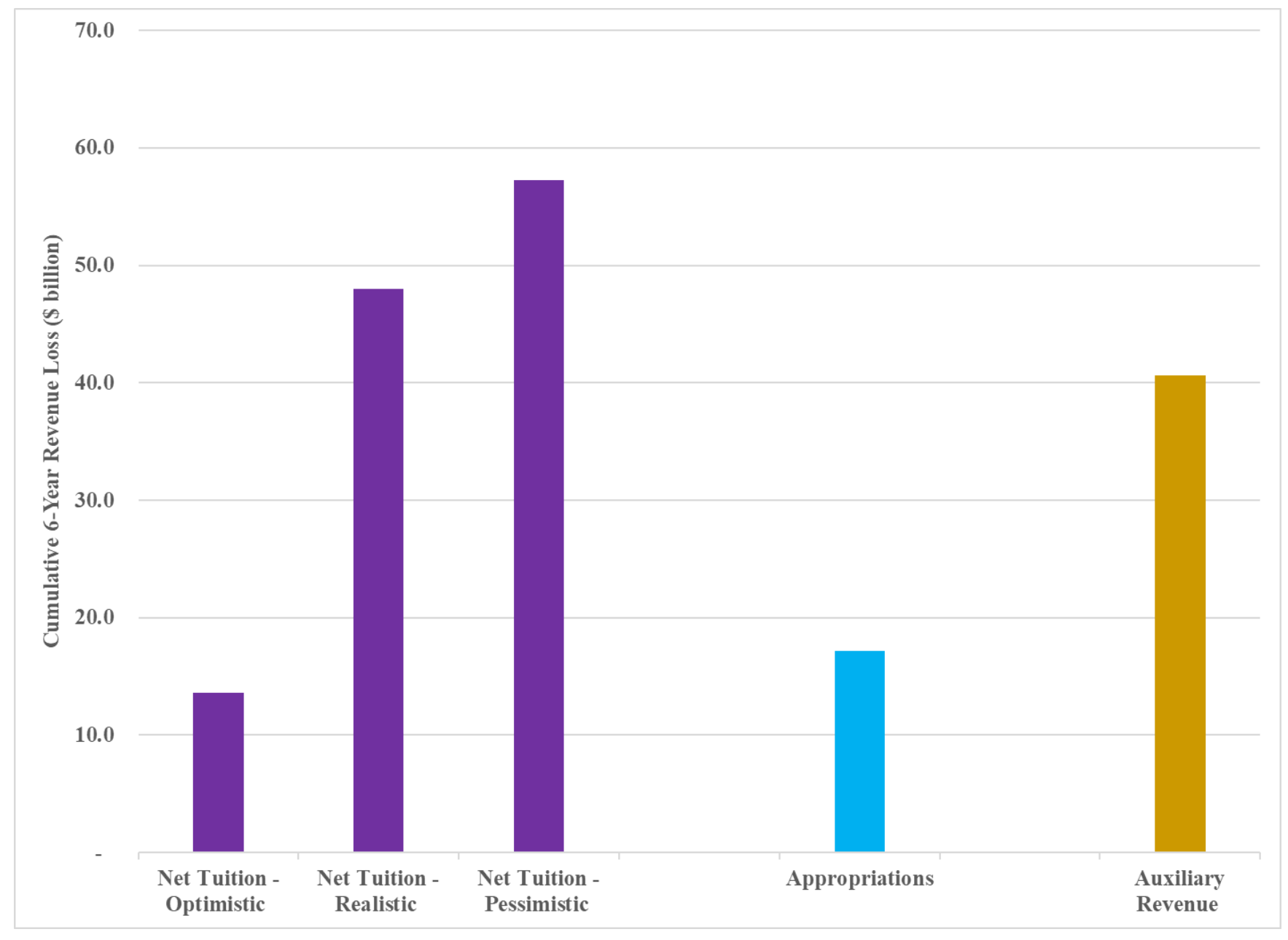

Notes: Cumulative revenues are calculated as a sum of annual revenue losses for 2020 through 2025 fiscal years. The optimistic scenario assumes a net tuition revenue loss in 2020 equal to the Title IV funding change and no losses in years 2021-2025.The realistic scenario assumes a net tuition revenue loss in 2020 equal to the Title IV funding change, then linear recovery over the following five years back to 2019 net tuition revenue level by 2026 . The pessimistic scenario assumes net tuition revenue losses in each year that are $20 \%$ more severe than the losses in the realistic scenario.

Source: Authors' calculations based on data from IPEDS (college finances), NASBO (revenue), SafeGraph (consumer mobility), SHEEO (appropriations), and Womply (consumer spending) 
Figure 6: Projected Six-Year Cumulative Revenue Loss, by Revenue Type and Sector

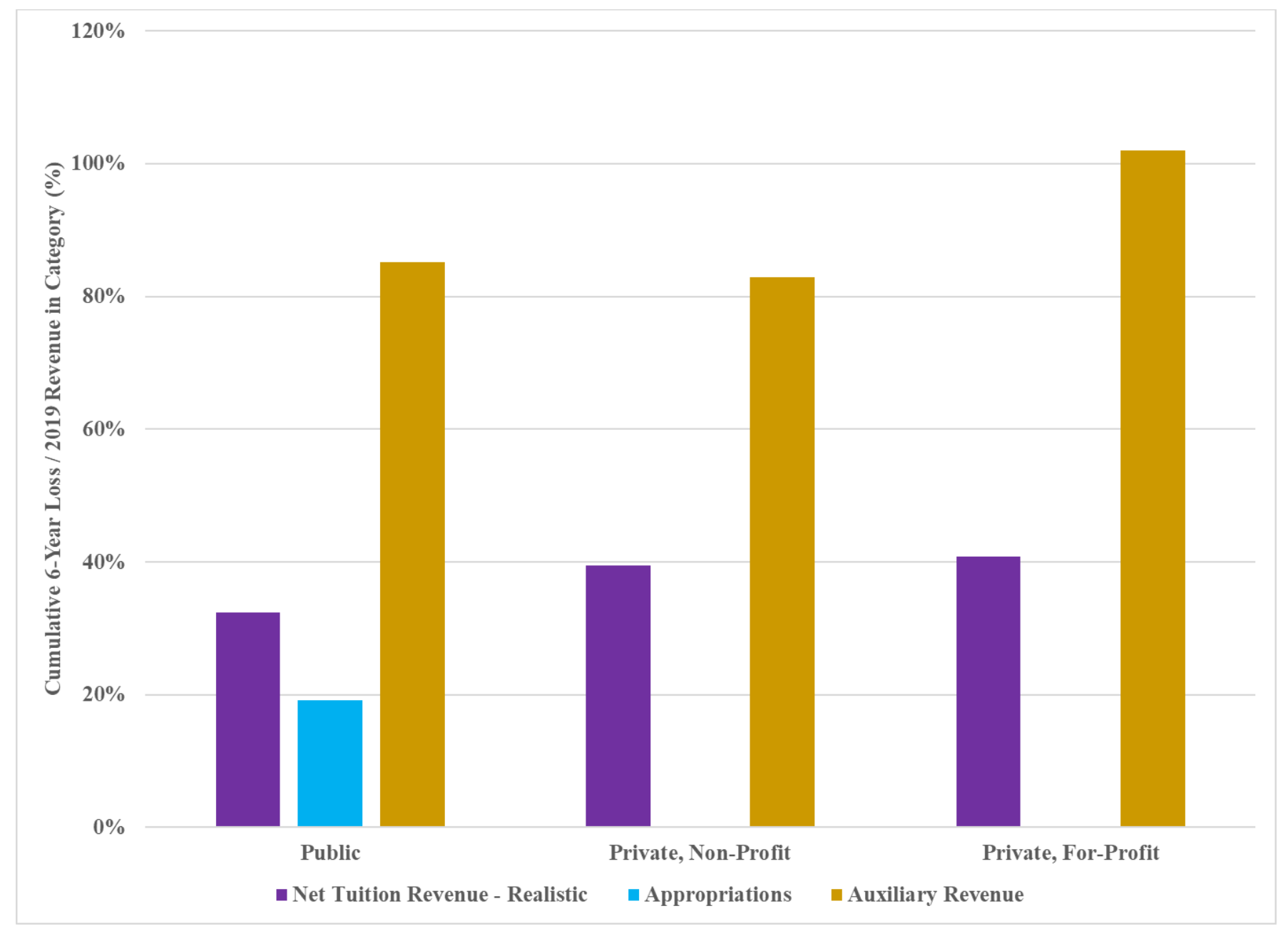

Notes: This figure displays cumulative revenue losses in each category as a share of fiscal year 2019 revenue from a particular source (sum of annual revenue losses in category for 2020 through 2025 fiscal years divided by fiscal year 2019 revenue for that revenue source). All estimates produced under the assumptions of the realistic scenario - a net tuition revenue loss in 2020 equal to the Title IV funding change, then linear recovery over the following five years back to 2019 net tuition revenue level by 2026 .

Source: Authors' calculations based on data from IPEDS (college finances), NASBO (revenue), SafeGraph (consumer mobility), SHEEO (appropriations), and Womply (consumer spending) 


\section{Figure 7: Incidence of Financial Distress, by Institution Type}

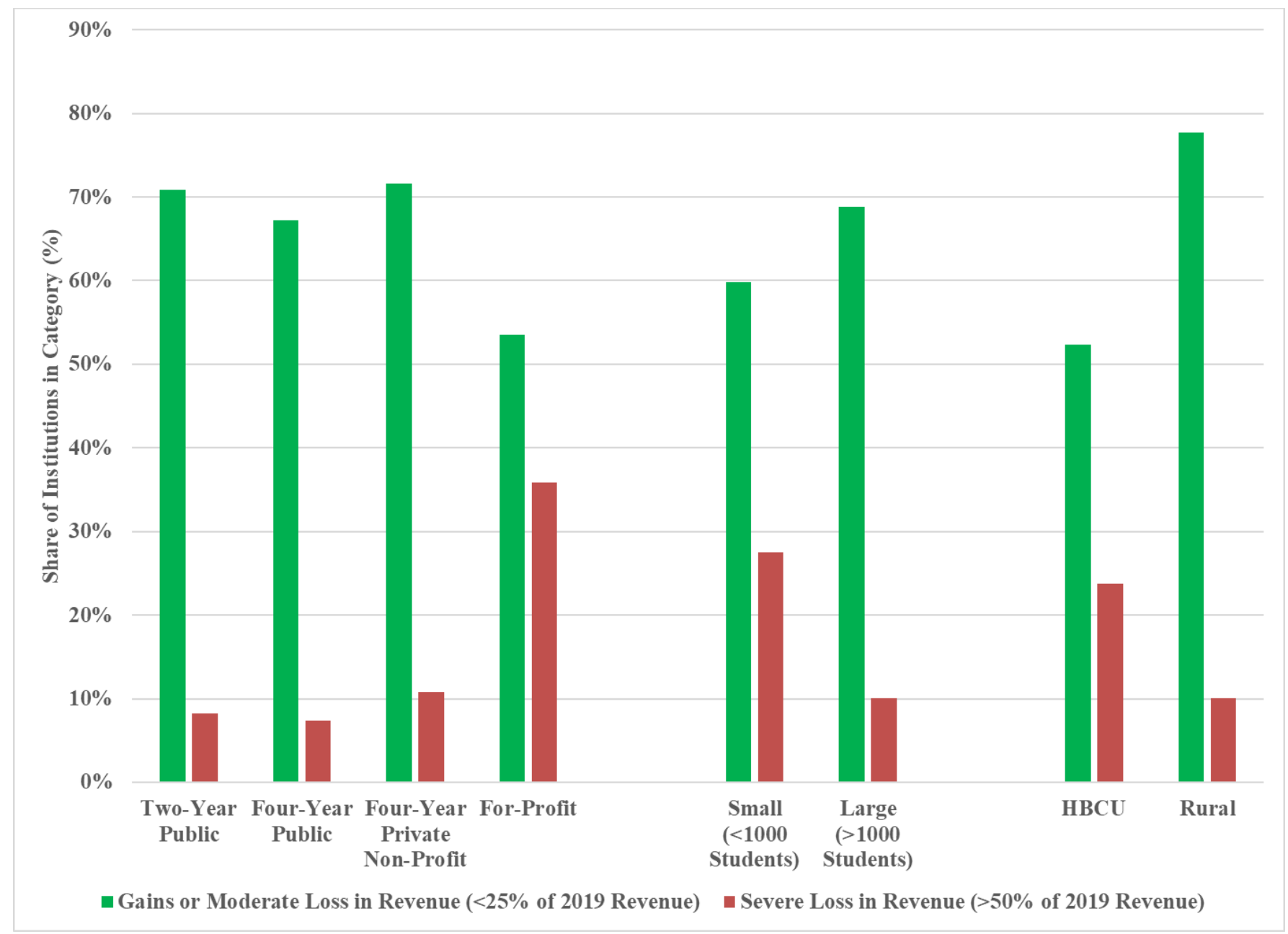

Notes: This figure displays the share of institutions in each category with moderate versus severe loss of cumulative revenues from net tuition revenue, appropriations, and auxiliary revenue (sum of total annual revenue losses for 2020 through 2025 fiscal years divided by fiscal year 2019 total revenue). All estimates produced under the assumptions of the realistic scenario - a net tuition revenue loss in 2020 equal to the Title IV funding change, then linear recovery over the following five years back to 2019 net tuition revenue level by 2026. HBCU = Historically Black College or University

Source: Authors' calculations based on data from IPEDS (college finances), NASBO (revenue), SafeGraph (consumer mobility), SHEEO (appropriations), and Womply (consumer spending) 


\section{Appendix}

\section{Table 1A: Incidence of Financial Distress as a Share of Students, by Institution Type}

\begin{tabular}{|c|c|c|c|c|c|}
\hline \multirow[b]{2}{*}{ Institution Type } & \multirow[b]{2}{*}{ \# Students } & \multicolumn{4}{|c|}{ Cumulative Revenue Loss } \\
\hline & & No Loss & $\begin{array}{l}\text { Loss }<25 \% \text { of } \\
2019 \text { Revenue }\end{array}$ & $\begin{array}{c}25 \%<=\text { Loss }< \\
\mathbf{5 0} \% \text { of } \mathbf{2 0 1 9} \\
\text { Revenue }\end{array}$ & $\begin{array}{c}\text { Loss }>=50 \% \text { of } \\
2019 \text { Revenue }\end{array}$ \\
\hline Two-Year Public & $8,220,182$ & $1 \%$ & $68 \%$ & $26 \%$ & $5 \%$ \\
\hline Four-Year Public & $11,109,286$ & $1 \%$ & $70 \%$ & $26 \%$ & $4 \%$ \\
\hline Four-Year Non-Profit & $5,196,892$ & $8 \%$ & $65 \%$ & $14 \%$ & $12 \%$ \\
\hline Other (mostly for-profit) & $2,159,232$ & $34 \%$ & $35 \%$ & $6 \%$ & $24 \%$ \\
\hline Small ( $<1000$ students) & 767,952 & $28 \%$ & $32 \%$ & $13 \%$ & $27 \%$ \\
\hline Large (>1000 students) & $25,917,640$ & $4 \%$ & $67 \%$ & $22 \%$ & $7 \%$ \\
\hline $\mathrm{HBCU}$ & 347,419 & $2 \%$ & $59 \%$ & $25 \%$ & $14 \%$ \\
\hline Rural & $1,674,842$ & $4 \%$ & $76 \%$ & $15 \%$ & $6 \%$ \\
\hline Total & $26,685,592$ & $5 \%$ & $66 \%$ & $22 \%$ & $7 \%$ \\
\hline
\end{tabular}

Notes: This table displays the share of students in each institution category attending institutions with different thresholds of cumulative revenue loss from net tuition revenue, appropriations, and auxiliary revenue (sum of total annual revenue losses for 2020 through 2025 fiscal years divided by fiscal year 2019 total revenue). All estimates produced under the assumptions of the realistic scenario - a net tuition revenue loss in 2020 equal to the Title IV funding change, then linear recovery over the following five years back to 2019 net tuition revenue level by 2026. HBCU = Historically Black College or University

Source: Authors' calculations based on data from IPEDS (college finances), NASBO (revenue), SafeGraph (consumer mobility), SHEEO (appropriations), and Womply (consumer spending) 


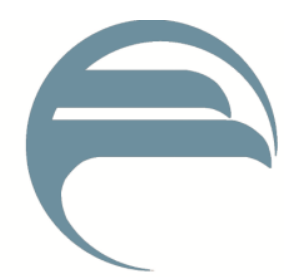

FEDERAL Reserve BANK of PHILADELPHiA

Consumer Finance Institute Discussion Paper Series

http://www.philadelphiafed.org/consumer-finance-institute 